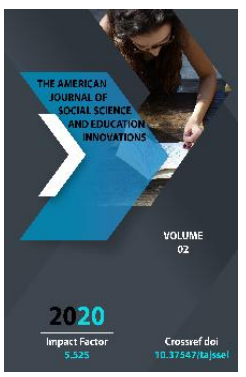

\title{
The Image Of Al-Hakim At-Termizi Is On The Uzbek Stage
}

Faxriddin Abduvohidov

Phd Student, Uzbek State Art And Of The Institute Of Culture, Tashkent, Uzbekistan

Journal Website:

http://usajournalshub.c

om/index,php/tajssei

Copyright: Original

content from this work

may be used under the

terms of the creative

commons attributes

4.0 licence.

\section{ABSTRACT}

The article deals with the theatrical interpretation of the image of Hakim at-Termizi, one of the leaders of the Transoxiana scholars, who in the Middle Ages made a great contribution to the development of world science, in particular, Islamic teachings, created valuable works that contain "authentic" hadiths.

\section{KEYWORDS}

Theater, dramaturgy, theme, genre, character, fable, monologue, action, actor, director, composition, artistic idea.

\section{INTRODUCTION}

Many medieval scholars made invaluable contributions to the development of the religious sciences as well as the secular sciences. Religious sciences have already played an important role in the development of society, the development of people, the formation of their worldview, so the example of these great personalities, the way of life, the invaluable heritage and spiritual values left by them to our people through research, research, art. Ensuring that it makes an important contribution to the spirituality and upbringing of the younger generation is one of the most pressing issues today. In order to 
raise the work in this area to a new level, a number of decrees and resolutions of the President have been issued, and intensive research is being conducted to further improve the religious and educational sphere. The International Center for Islamic Civilization, Islamic Academy, mosques and madrasas have been established to study the invaluable heritage of our great ancestors, to convey the purity of Islam to the world community, and to develop our people, especially our youth, as highly spiritual and cultured people.

As the first President of the Republic of Uzbekistan Islam Karimov noted, "Secular and religious sciences, especially those related to Islam, which have become an integral part of universal civilization and culture, have grown to the highest level in the history of this great land, where great people, scholars, politicians and commanders grew up. It gives us great pride and pride that the services of the great scholars who were born and raised in our motherland are incomparable in their rise "[1.1].

Abu Abdullah Muhammad ibn Ali Hakim Termezi, who made a great contribution to the development of world science in the Middle Ages, in particular, several branches of Islamic science, is one of the leaders of the Transoxiana scholars. Hakim al-Tirmidhi, who was almost contemporary with hadith scholars such as Imam Darimi, Imam Bukhari, and Imam al-Tirmidhi, who worked in the "golden age" of the science of hadith, was engaged in regulating the Sunnah of the Prophet (pbuh) and defining the terms of hadith. In contrast to these famous hadith scholars, who created valuable works that contained hadiths, they have a special place with their fruitful work, rich in instructions on in-depth analysis of hadiths, their essence, understanding of wisdom and its application to human life.

\section{MATERIALS AND METHODS}

Muhammad ibn Ali Abu Abdullah al-Hakim alTermizi (824-892) was a Sufi thinker who was well versed in hadith and jurisprudence. His contemporaries called Al-Hakim al-Termizi "the sage from Termez" because of his breadth of worldview and deep thinking.

Al Hakim at-Termizi lived and worked in 820932 and made an invaluable contribution to Islamic teaching. His deep knowledge and incomparable potential have been highly praised by many scholars. The great thinkers Abdurahman Jami in his work "Nafaot ul-uns" and Alisher Navoi in his book "Nasaim ulmuhabbat" mentioned him as one of the greatest sheikhs and included him in the second line of imagination. Alisher Navoi gives the following information about al-Hakim at Termizi: "He is the second layer. His name is Abu Abdullah. Mashayikh is arrogant and has had conversations with Abu Turab Nahshabi and Ahmad Khizrawaih and Ahmad Khizrawaih and Ibn Jalla, and there are many hadiths and apparent karamat and tasanifi (written works). In particular, he has the books Hatm ul-vilaya and Nahaj, Nawadir ul-Usul and other books, and he is the originator of a commentary (Qur'anic commentary). But they do not fulfill it (the end) ... "Hodja Bahauddin Naqshband and his commentary on al-Hakim al-Tirmidhi: ] describes his high career and status with special grace. Fariddin Attar describes it as "Shaykh al-Islam, he is perfect in the saint's sunnah, the leader of the nation's great scholars, the only one of the pure" [2.7]. The way of life and multifaceted activities of such great compatriots began to be regularly studied by our scientists, mainly after the independence of our country. 
During his visit to Surkhandarya region, President of the Republic of Uzbekistan Shavkat Mirziyoyev visited the Hakim Termizi complex and gave recommendations on the study, promotion and beautification of the heritage of great scholars. emphasizes that all favorable conditions have been created [1.3].

Today, effective research is being conducted on the scientific basis of the invaluable treasure created by our ancestors over the centuries, to make it an integral part of our worldview. It is an important task to convey to our people the exemplary way of life of our great scholars, the legacy they have left through literature, art, especially theatrical art. For this purpose, historian Ubaydulla Uvvatov also researched the creative work of al Hakim at Termizi and created a historical drama together with a number of articles, pamphlets and director Giyas Shermuhammad. Historical plays are a source of aesthetic pleasure and passion for theatrical art. providing in-depth and comprehensive information about the past and its celebrities, has the potential to raise the awareness of citizens. The activities of great ancestors - scientists, thinkers, kings and warlords, representatives of culture and art, their life courage, their services to the fate of the motherland and sealed in the pages of history play an important role in the spiritual formation and development of citizens. The Uzbek National Drama Theater has written a number of dramatic works about historical figures, most of which have been staged. However, dramas that fully reflect the lives and activities of religious scholars are rarely staged. The drama "Allomai zamon", created by Ubaydulla Uvvatoz and Giyas Shermuhammad, was a great result of research in this area.
The main director of the theater Mansur Ravshanov in the staging of the play "Allomai zamon" approaches the work with an in-depth study of the period of Hakim at Termizi, his life, and tries to bring the team into the historical environment. In order to ensure the historical authenticity and artistic integrity of the play, the director invites the Deputy Chairman of the Muslim Board of Uzbekistan Sheikh Abdulaziz Mansur as a religious adviser, well-known literary scholar Shukhrat Rizaev as a literary adviser, Bakhtiyor Turaev as an artist. Thanks to the creative collaboration, a large-scale performance depicting Termez's life was created. In understanding the environment of the period in which the great scientist lived, and in providing an artistic solution to the play, the views of the director and the artist were in harmony. The majestic stage decorations created by the artist B.Turaev stand out with their design in accordance with the idea of the work. Each stage design designed by the artist serves to reveal the character of Termez. It is also noteworthy that more than seventy performers were allowed to move freely in accordance with the scenery of the stage. Keeping the stage interpretation of a great work in step, developing it step by step, required serious responsibility and high skill from the director and the artist. As a result of M.Ravshanov's skillful management of this process, an artistic integrity, a whole ensemble is formed on the stage.

During the events of the play, the exemplary life of Hakim Termizi, who lost his father early, devoted his whole life to learning in accordance with his mother's teachings, suffered various injustices, did not give up his goals and aspirations even in difficult conditions, created many works for the spiritual maturity of future generations. The various curses and slanders inflicted on 
Termez during the conflicting events did not bend his stature, on the contrary, his relentless, arduous pursuit of knowledge led the scholar to happy days. She shines a light as a singer of goodness.

The monumental stage decoration developed by B. Turaev plays an important role in enhancing the impact of the play and the full revival of the image of Hakim Termizi. The scenery, which alternates between the content of the events, is sometimes reminiscent of the mausoleums of Termez, sometimes a holy book that shared knowledge and enlightenment with Termez, and sometimes a huge tree that always invites humanity to its bosom. The majestic stage decoration is also one of the main means of ensuring the glory of the image of al-Hakim atTermizi.

During the events of the play, al-Hakim alTirmidhi, after the death of his father, took lessons in tafsir, hadith, and jurisprudence from mature scholars in his hometown. His mother fell ill when she decided to go to Baghdad, one of the largest centers of science and enlightenment in the East. Although he could not go to Baghdad, he never backed down from his education. He took lessons from great scholars and studied the science of hadith and Islamic literature. But like Eshqabil, who has not seen his knowledge and high status, he wants to stand in his way. Despite various pressures, Hakim Termezi achieves his goal.

The skill of the lead and lead actors serves to ensure the success of the play. The director entrusts the role of Hakim at Termizi to F. Boltaev, an experienced actor, who deeply studies the life of the protagonist, who deeply understands the task, depicts the age of the scientist, his behavior, his humility, and his lack of ambition for fame. Termizi, created by F. Boltaev, stands firm in the way of Allah in any situation and does not pay much attention to the sufferings of such lowly people as Eshanqul (A. Panjiev). On the contrary, they travel the world, increase their knowledge, make disciples, write books (sources say that the scientist wrote about 400 books, and only 60 of them have reached us) and reach great heights. These processes are convincingly, sincerely interpreted by the actor, ensuring that the inner spiritual world of the image is fully revealed.

The image of the mother performed by D.Yunusalieva is manifested as a person who sacrificed his whole life for the perfection of his child, who helped Hakim Termizi in difficult conditions, who was a shield, a shy, kind, benevolent, prayerful person. The performances of honored artists of Uzbekistan H. Aripov in the roles of Ismail Somoni, H. Nasriddinov in the roles of Imam Bukhari are interpreted in different ways, which attracts the attention of the audience. This indicates that the creative team has done serious research on the staging of the work.

\section{CONCLUSION}

Stage works such as "Allomai zamon" play an important role in constantly studying and applying the exemplary way of life, scientific and creative heritage of our great compatriots in our history, that is, educating young people as spiritually mature people through artistic and theatrical works [2.4]. It is true that the study of religious teachings, which are the basis of spiritual and spiritual education today, issues related to spirituality, such as knowledge, faith, morality, sanctity of the homeland, the works of our great ancestors, the application of their teachings to the hearts of young people. . Therefore, in a number of 
decrees and resolutions aimed at further development of culture and art, at a historic meeting with intellectuals, in the concept of development of national culture, in the first paragraph of the five initiatives, the President paid special attention to theatrical art. The glorious history, the way of life of our ancestors, the scientific and creative activity of our ancestors through the staging of historical periods, historical figures, commanders, religious figures, scientific and creative activities in the positive impact on the spirituality of young people. in which case it is advisable to bring it to the stage. After all, the presentation of our historical values on stage serves to further deepen the national spirit in the minds of the audience.

\section{REFERENCES}

1. Karimov I.A. High spirituality is an invincible force. - Tashkent: Manaviyat, 2008.

2. Karimov I. A. Solemn speech dedicated to the 2500th anniversary of the city of Termez. T .: Uzbekistan. 2001.

3. Mirziyoev Sh.M. The development of literature and art, culture is a solid foundation for the development of the spiritual world of our people. 2017. August 4 // People's speech

4. Abdusamatov H. History and artistic interpretation. - Tashkent: Ghafur Ghulam Publishing House of Literature and Art, 1995. $-184 \mathrm{p}$.

5. Abdusamatov H. Drama theory. - Tashkent: Ghafur Ghulam Publishing House of Literature and Art, 2000. -288 p.

6. Islomov T. History and scene. - Tashkent: Gafur Gulom Publishing House of Literature and Art, 1998. -136 p.

7. Rahmatullaeva D. Uzbek theater: historical drama. - Tashkent: San'at, 2004.-326 p.
8. Tursunov T. History of Uzbek theater of the XX century (1900-2007). - Tashkent: Art Press, 2010. $-568 \mathrm{p}$.

9. Tursunboev $S$. The boundaries of the Uzbek theater. - Tashkent: UzDSI, 2010. $308 \mathrm{p}$.

10. Uvvatov U. Usmonov U. Two scholars from Termez. - Tashkent: Islamic University Publishing and Printing Association, 2017, $138 \mathrm{p}$.

11. Rizaev.A. Eritage Of Classics On The Stage Of The Uzbek Theater (page 5-12) Asian Studies ISSN 0970-7301 Vol-37-Issue-2-JulyDecember-2019.

12. Rizaev.A. Journal of Adv Research in Dynamical \& Control Systems, (JARDCS) (page 2773-2776) Vol. 12, Issue-02, 2020. 